\title{
Physiological response of a golden tide alga (Sargassum muticum) to the interaction of ocean acidification and phosphorus enrichment
}

\author{
Zhiguang $\mathrm{Xu}^{1,2}$, Guang Gao ${ }^{1,3}$, Juntian $\mathrm{Xu}^{1}$, and Hongyan $\mathrm{Wu}^{4}$ \\ ${ }^{1}$ Marine Resources Development Institute of Jiangsu, Huaihai Institute of Technology, Lianyungang 222005, China \\ ${ }^{2}$ Marine Biology Institute of Shandong Province, Qingdao 266104, China \\ ${ }^{3}$ School of Marine Science and Technology, Ridley Building, Newcastle University, Newcastle upon Tyne, NE1 7RU, UK \\ ${ }^{4}$ Hubei University of Technology, Wuhan 430068, China \\ Correspondence to: Guang Gao (biogaoguang@126.com)
}

Received: 27 September 2016 - Discussion started: 17 October 2016

Revised: 23 December 2016 - Accepted: 13 January 2017 - Published: 10 February 2017

\begin{abstract}
The development of golden tides is potentially influenced by global change factors, such as ocean acidification and eutrophication, but related studies are very scarce. In this study, we cultured a golden tide alga, Sargasssum muticum, at two levels of $p \mathrm{CO}_{2}$ (400 and $\left.1000 \mu \mathrm{atm}\right)$ and phosphate $(0.5$ and $40 \mu \mathrm{M})$ to investigate the interactive effects of elevated $p \mathrm{CO}_{2}$ and phosphate on the physiological properties of the thalli. Higher $p \mathrm{CO}_{2}$ and phosphate $(\mathrm{P})$ levels alone increased the relative growth rate by 41 and $48 \%$, the net photosynthetic rate by 46 and $55 \%$, and the soluble carbohydrates by 33 and $62 \%$, respectively, while the combination of these two levels did not promote growth or soluble carbohydrates further. The higher levels of $p \mathrm{CO}_{2}$ and $\mathrm{P}$ alone also enhanced the nitrate uptake rate by 68 and $36 \%$, the nitrate reductase activity (NRA) by 89 and $39 \%$, and the soluble protein by 19 and $15 \%$, respectively. The nitrate uptake rate and soluble protein was further enhanced, although the nitrate reductase activity was reduced when the higher levels of $p \mathrm{CO}_{2}$ and $\mathrm{P}$ worked together. The higher $p \mathrm{CO}_{2}$ and higher $\mathrm{P}$ levels alone did not affect the dark respiration rate of the thalli, but together they increased it by $32 \%$ compared to the condition of lower $p \mathrm{CO}_{2}$ and lower P. The neutral effect of the higher levels of $p \mathrm{CO}_{2}$ and higher $\mathrm{P}$ on growth and soluble carbohydrates, combined with the promoting effect on soluble protein and dark respiration, suggests that more energy was drawn from carbon assimilation to nitrogen assimilation under conditions of higher $p \mathrm{CO}_{2}$ and higher $\mathrm{P}$; this is most likely to act against the higher $p \mathrm{CO}_{2}$ that caused acid-base perturbation via synthesizing $\mathrm{H}^{+}$transport-related protein. Our results indicate that ocean acidification and eu-
\end{abstract}

trophication may not boost golden tide events synergistically, although each one has a promoting effect.

\section{Introduction}

Sargassum C. Agardh (1820) is the most species-rich genus in the Phaeophyta and has a global distribution (Mattio and Payri, 2011). The species of this genus constitutes an important part of the marine flora and is considered a valuable and unique habitat for a number of highly adapted marine animal species (Laffoley et al., 2011). Some species of Sargassum are economically important and are used in animal fodder, agricultural manure, and alginate production (Ashok-Kumar et al., 2012; Fenoradosoa et al., 2010; González-López et al., 2012). On the other hand, Sargassum is an aggressive genus, and it can rapidly spread and invade new areas (Sfriso and Facca, 2013). The invasion of Sargassum would accordingly compete with indigenous species for nutrients and light, leading to the alteration of the macroalgal community structure (Rueness, 1989; Stæhr et al., 2000). For instance, the increased abundance of S. muticum in Limfjorden (Denmark) between 1990 and 1997 led to decreased cover of several indigenous species belonging to the genera Codium, Fucus, and Laminaria, and thus reduced the species richness and diversity of the macroalgal community (Stæhr et al., 2000). Recently, species of Sargassum have inundated the coasts along the Gulf of Mexico, West Africa, the Caribbean, and Brazil in unprecedented biomass, which are termed golden tides (Schell et al., 2015; Smetacek and Zingone, 2013). Apart 
from the negative effect on aesthetics and tourism, the occurrence of golden tides could kill the fish within the algal mass, mainly due to hypoxia or anoxia in the waters caused by decomposition of Sargassum thalli (Cruzrivera et al., 2015). In addition, the dense Sargassum accumulation could clog fishing nets and impede the passage of boats, leading to food shortages for local people who depend on artisanal fisheries (Smetacek and Zingone, 2013). The occurrence of golden tides has been linked to higher nutrient levels in seawater (Lapointe, 1995; Smetacek and Zingone, 2013). The distribution pattern and biomass of Sargassum spp. are environmentdependent (temperature, light, nutrients, etc.) (Ang, 2006; Sfriso and Facca, 2013).

Due to the burning of fossil fuels and changes in land use, the atmospheric concentrations of carbon dioxide increased to the level of 401.72 ppm in July 2016 (http://www. esrl.noaa.gov/gmd/ccgg/trends/global.html), which is an unprecedented high over the last 800000 years (IPCC, 2013). When $\mathrm{CO}_{2}$ dissolves in seawater, it forms carbonic acid, and as more $\mathrm{CO}_{2}$ is taken up by the ocean's surface, the $\mathrm{pH}$ decreases, moving towards a less alkaline and therefore more acidic state; this is termed ocean acidification. The mean surface ocean $\mathrm{pH}$ has already decreased by 0.1 units since the beginning of the industrial era, corresponding to a $26 \%$ increase in hydrogen ion concentration (IPCC, 2013). By 2100, concentrations of $\mathrm{CO}_{2}(\mathrm{aq})$ and $\mathrm{HCO}_{3}^{-}$are predicted to increase by 192 and $14 \%$, respectively, and $\mathrm{CO}_{3}^{2-}$ is predicted to decrease by $56 \%$ with a concomitant decline in $\mathrm{pH}$ to 7.65 (Raven et al., 2005). Increased $\mathrm{CO}_{2}$ could exert positive, neutral, or negative effects on the physiological properties of macroalgae ( $\mathrm{Ji}$ et al., 2016; Wu et al., 2008). In terms of Sargassum species, increased $\mathrm{CO}_{2}(800 \mathrm{ppm})$ enhanced the photosynthetic rate (based on $\mathrm{CO}_{2}$ uptake) in $S$. muticum (Longphuirt et al., 2014). On the other hand, the same level of increased $\mathrm{CO}_{2}$ (750 ppm) did not affect growth, Rubisco's maximal activity, affinity for $\mathrm{CO}_{2}$, or quantity in $S$. vulgare (Alvaro and Mazal, 2002). Furthermore, increased $\mathrm{CO}_{2}$ (750 ppm) significantly decreased the net photosynthetic rate and light saturation point of S. henslowianum (Chen and Zou, 2014).

Apart from ocean acidification, eutrophication is another environmental challenge. Eutrophication can occur naturally in lakes through the transfer of nutrients from the sediment to the water via living or decomposing macrophytes, resuspension, diffusion, and bioturbation (Carpenter, 1981). However, anthropogenic activities have accelerated the rate and extent of eutrophication (Carpenter et al., 1998). The inevitable urbanization of a growing human population, the increased use of coastal areas, and rising fertilizer use for agricultural intensification has led to accelerated nutrient inputs from land water to coastal waters (Smith et al., 1999). These changes in nutrient availability result in eutrophication, an increasing threat for coastal ecosystems (Bricker et al., 2008). One consequence of eutrophication is that it can lead to algal bloom, such as green tides and golden tides (Smetacek and Zingone, 2013). There are intensive studies regarding the effect of nutrients on the physiological properties of Sargassum species (Hwang et al., 2004; Incera et al., 2009; Lapointe, 1995; Liu and Tan, 2014; Nakahara, 1990). Enrichment of nutrients can usually enhance the growth and photosynthetic parameters of Sargassum. For instance, the growth rate of $S$. baccularia almost doubled when nutrients increased from $3 \mu \mathrm{M}$ ammonium plus $0.3 \mu \mathrm{M}$ phosphate to $5 \mu \mathrm{M}$ ammonium plus $0.5 \mu \mathrm{M}$ phosphate (Schaffelke and Klumpp, 1998), and the photosynthetic rates of $S$. fluitans and $S$. natans were also 2-fold higher with $0.2 \mathrm{mM} \mathrm{PO}_{4}^{3-}$ enrichment compared to the control (Lapointe, 1986). Furthermore, some studies have demonstrated that macroalgae experience more phosphorus limit than nitrogen limit (Lapointe, 1986; Lapointe et al., 1987, 1992; Littler et al., 1991). For instance, nitrogen enrichment did not affect the growth rates of $S$. fluitans or $S$. natans, while phosphorus enrichment increased them from 0.03-0.04 (control) to $0.05-0.08$ doublings d $^{-1}$ (Lapointe, 1986).

Neither ocean acidification nor eutrophication is proceeding in isolation; rather, they occur simultaneously, particularly in coastal areas. The interactive effects of the two factors may be completely different or of greater magnitude compared to the effects of any single stressor. To the best of our knowledge, no studies have been reported regarding the interactive effects of ocean acidification and eutrophication on Sargassum. In this study, we chose the species $S$. muticum to investigate its responses to the interaction of ocean acidification and eutrophication. S. muticum is an invasive macroalga that commonly inhabits rocky shores (Karlsson and Loo, 1999). It originates from Japan and was imported to the Northern Pacific coast of the United States in the early 20th century (Scagel, 1956). It was also introduced to Europe along with the Japanese oyster in the late 1960s (Jones and Farnham, 1973). Its distribution is now worldwide due to its introduction and subsequent rapid expansion (Cheang et al., 2010). Our study supplies insight into how ocean acidification and eutrophication affect the physiological properties of S. muticum and thus the development of golden tides.

\section{Materials and methods}

\subsection{Sample collection and experimental design}

S. muticum was collected from lower intertidal rocks on the coast of Lidao, Rongcheng, China $\left(37^{\circ} 15^{\prime} \mathrm{N}, 122^{\circ} 35^{\prime} \mathrm{E}\right)$. The samples were transported to the laboratory in an insulated polystyrene cooler $\left(4-6^{\circ} \mathrm{C}\right)$ within $3 \mathrm{~h}$. Healthy thalli were selected and rinsed with sterile seawater to remove sediments, epiphytes, and small grazers. The thalli were maintained in an intelligent illumination incubator (MGC-250P, Yiheng Technical Co. Ltd., Shanghai, China) for $24 \mathrm{~h}$ before the experiment. The temperature in the incubator was set at $20^{\circ} \mathrm{C}$ with a $12 \mathrm{~h}-12 \mathrm{~h}$ (light-dark) photoperiod of 
$150 \mu$ mol photons $\mathrm{m}^{-2} \mathrm{~s}^{-1}$ photosynthetically active radiation (PAR). After the maintenance, a two-way factorial experiment was set up to investigate the interactive effects of $p \mathrm{CO}_{2}$ and phosphate on $S$. muticum. The thalli were placed in $3 \mathrm{~L}$ flasks with $2 \mathrm{~L}$ of sterile seawater (one thallus per flask) and cultured at fully crossed two $p \mathrm{CO}_{2}(400 \mu \mathrm{atm}$, lower $p \mathrm{CO}_{2}, \mathrm{LC} ; 1000 \mu \mathrm{atm}$, higher $\left.p \mathrm{CO}_{2}, \mathrm{HC}\right)$ and two phosphate $(0.5 \mu \mathrm{M}$, lower phosphate, LP; $40 \mu \mathrm{M}$, higher phosphate, HP) levels with continuous aeration for 13 days. Phosphorus was selected as a nutrient variable, because some findings have displayed that phosphorus, rather than nitrogen, is the primary limiting nutrient for macroalgae (Lapointe, 1986; Lapointe et al., 1987, 1992; Littler et al., 1991). The conditions of natural seawster are $400 \mu$ atm $p \mathrm{CO}_{2}$ and $0.5 \mu \mathrm{M}$ phosphate. The $400 \mu$ atm $p \mathrm{CO}_{2}$ was achieved by bubbling ambient air and $1000 \mu \mathrm{atm} p \mathrm{CO}_{2}$ was obtained through a $\mathrm{CO}_{2}$ plant chamber (HP1000 G-D, Wuhan Ruihua Instrument \& Equipment Ltd, China) with a $\mathrm{CO}_{2}$ variation of less than $5 \%$. The higher P level $(40 \mu \mathrm{M})$ was achieved by adding $\mathrm{NaH}_{2} \mathrm{PO}_{4}$ to natural seawater, and the nitrate concentration was set at $200 \mu \mathrm{M}$ for all treatments to avoid $\mathrm{N}$ limit. The media were refreshed every day.

\subsection{Carbonate chemistry parameters}

The seawater $\mathrm{pH}$ was recorded with a $\mathrm{pH}$ meter ( $\mathrm{pH} 700$, Eutech Instruments, Singapore), and total alkalinity (TA) was measured by titrations. The salinity of the seawater was 29 . Other carbonate system parameters, which were not directly measured, were calculated via CO2SYS (Pierrot et al., 2006) using the equilibrium constants of $K_{1}$ and $K_{2}$ for carbonic acid dissociation (Roy et al., 1993).

\subsection{Measurement of growth}

The growth of S. muticum was determined by weighing fresh thalli. The thalli of $S$. muticum were blotted gently with tissue paper to remove water on the surface from the thalli before weighing them. The relative growth rate (RGR) was estimated as follows: $\mathrm{RGR}=\left(\ln W_{t}-\ln W_{0}\right) / t \times 100$, where $W_{0}$ is the initial fresh weight $(\mathrm{FW})$ and $W_{t}$ is the weight after $t$ days of culture.

\subsection{Determination of photosynthesis and respiration}

The net photosynthetic rate of the thalli was measured by a Clark-type oxygen electrode (Chlorolab-3, Hansatech, Norfolk, UK) at the end of the experiment. Approximately $0.1 \mathrm{~g}$ of fresh-weight algae harvested from the culture flask was transferred to the oxygen electrode cuvette with $8 \mathrm{~mL}$ of sterilized media, and the media were stirred during measurement. The irradiance and temperature conditions were set the same as in the growth incubators. The increase of oxygen content in seawater within 5 min was defined as the net photosynthetic rate, and the decrease of oxygen content in seawater in darkness within 10 min was defined as the respi- ration rate. The net photosynthetic rate (NPR) and respiration rate were presented as $\mu \mathrm{mol} \mathrm{O} \mathrm{g}^{-1} \mathrm{FW} \mathrm{h}^{-1}$.

Photosynthetic rates at different dissolved inorganic carbon (DIC) levels were measured under saturating irradiance of $600 \mu \mathrm{mol}$ photons $\mathrm{m}^{-2} \mathrm{~s}^{-1}$ at the end of the experiment. The various DIC concentrations $(0-13.2 \mathrm{mM})$ were obtained by adding different amounts of $\mathrm{NaHCO}_{3}$ to the Tris-buffered DIC-free seawater. DIC was removed from the natural seawater by reducing $\mathrm{pH}$ to approximately 4.0 with the addition of $1.0 \mathrm{M} \mathrm{HCl}$ and then sparging for $2 \mathrm{~h}$ with pure $\mathrm{N}_{2}$ gas $(99.999 \%)$. Finally, Tris buffer $(25 \mathrm{mM})$ was added and the $\mathrm{pH}$ was adjusted to 8.1 with freshly prepared $1 \mathrm{M} \mathrm{NaOH}$ and $1 \mathrm{M} \mathrm{HCl}$. The parameters, which are the maximum photosynthetic rate $\left(V_{\max }\right)$ and the half saturation constant $\left(K_{0.5}\right.$, i.e., the DIC concentration required to give half of inorganic carbon $(\mathrm{Ci})$-saturated maximum rate of photosynthetic $\mathrm{O}_{2}$ evolution), were calculated from the Michaelis-Menten kinetics equation (Caemmerer and Farquhar, 1981)

$V=V_{\max } \times[S] /\left(K_{0.5}+[S]\right)$,

where $[S]$ is the DIC concentration.

\subsection{Assessment of photosynthetic pigments}

At the end of the experiment, approximately $100 \mathrm{mg}$ of freshweight thalli from each culture condition were ground thoroughly in $2 \mathrm{~mL} 80 \%$ acetone and placed in darkness for $12 \mathrm{~h}$. Then the homogenate was centrifuged for $10 \mathrm{~min}$ at $5000 \mathrm{~g}$ and the supernatant was used to determine Chl $a$ content spectrophotometrically according to the equation of Lichtenthaler (1987).

\subsection{Measurement of nitrate uptake rate}

The nitrate uptake rate (NUR) of the thalli was estimated from the decrease of $\mathrm{NO}_{3}^{-}$concentration in the culture medium over a given time interval $(12 \mathrm{~h})$ during the light period using the following equation: $\mathrm{NUR}=\left(\mathrm{N}_{0}-\right.$ $\left.N_{t}\right) \times V / W / 12$, where $N_{0}$ is the initial concentration of $\mathrm{NO}_{3}^{-}, N_{t}$ is the concentration after $12 \mathrm{~h}, V$ is the volume of the culture medium, and $W$ is the fresh weight of the thalli in culture. $\mathrm{NO}_{3}^{-}$concentration in the seawater was measured according to Strickland and Parsons (1972).

\subsection{Estimate of nitrate reductase activity}

The nitrate reductase activity of the thalli was assayed according to modified in situ method of Corzo and Niell (1991). The measurement was conducted during the local noon period (13:00 UTC $+8 \mathrm{~h}$ (Chinese Standard Time)), because the activity of nitrate reductase usually displays circadian periodicity; a maximum during the light period and a minimum in darkness (Deng et al., 1991; Velasco and Whitaker, 1989). Approximately $0.3 \mathrm{~g}(\mathrm{FW})$ of thalli from each culture condition was incubated for $1 \mathrm{~h}$ at $20^{\circ} \mathrm{C}$ in darkness in the reaction 
solution $(10 \mathrm{~mL})$, which contained $0.1 \mathrm{M}$ phosphate buffer, $0.1 \%$ propanol $(v / v), 50 \mathrm{mM} \mathrm{KNO}_{3}, 0.01 \mathrm{mM}$ glucose, and $0.5 \mathrm{mM}$ EDTA with a $\mathrm{pH}$ of 8.0. The mixture was flushed with pure $\mathrm{N}_{2}$ gas $(99.999 \%)$ for 2 min to obtain an anaerobic state before the incubation. The concentration of nitrite produced was determined colorimetrically at $540 \mathrm{~nm}$ (Zou, 2005). The NRA was expressed as $\mu \mathrm{mol} \mathrm{NO}_{2}^{-} \mathrm{g}^{-1} \mathrm{FW} \mathrm{h}^{-1}$.

\subsection{Analysis of biochemical composition}

At the end of the experiment, about $0.2 \mathrm{~g}$ of FW thalli from each culture condition were ground in a mortar with distilled water, and soluble carbohydrates were extracted in a water bath of $80^{\circ} \mathrm{C}$ for $30 \mathrm{~min}$. After being centrifuged for $10 \mathrm{~min}$ at $5000 \mathrm{~g}$, the supernatant was volumed to $25 \mathrm{~mL}$ with distilled water, and soluble carbohydrate content was determined by the phenol-sulfuric acid method (Kochert, 1978).

Approximately $0.2 \mathrm{~g}$ of $\mathrm{FW}$ thalli from each culture condition were ground in a mortar with extraction buffer $\left(0.1 \mathrm{~mol} \mathrm{~L}^{-1}\right.$ phosphate buffer, $\left.\mathrm{pH} 6.8\right)$ and then centrifuged for $10 \mathrm{~min}$ at $5000 \mathrm{~g}$. Soluble protein was estimated from the supernatant using the Bradford (1976) assay with bovine serum albumin as a standard.

\subsection{Data analysis}

Results were expressed as means of replicates \pm standard deviation. Data were analyzed using the software SPSS v.21. The data under every treatment conformed to a normal distribution (Shapiro-Wilk, $P>0.05$ ), and the variances can be considered equal (Levene's test, $P>0.05$ ). Two-way analysis of variance (ANOVA) was conducted to assess the effects of $p \mathrm{CO}_{2}$ and $\mathrm{P}$ on carbonate parameters, relative growth rate, net photosynthesis rate, $V_{\max }, K_{0.5}, \mathrm{Chl} a$, nitrate uptake rate, nitrate reductase activity, soluble carbohydrates, soluble protein, and dark respiration rate. Tukey's honest significance difference (HSD) was conducted for a post hoc investigation. A confidence interval of $95 \%$ was set for all tests.

\section{Results}

The effects of ocean acidification and $\mathrm{P}$ enrichment on seawater carbonate parameters were detected (Table 1). Twoway ANOVA analysis $(P=0.05)$ showed that $p \mathrm{CO}_{2}$ had a main effect on all parameters except TA, while $\mathrm{P}$ did not affect any parameter. A post hoc Tukey's HSD comparison $(P=0.05)$ showed that elevated $p \mathrm{CO}_{2}$ decreased $\mathrm{pH}$ by 0.31 at both $\mathrm{LP}$ and $\mathrm{HP}$ and $\mathrm{CO}_{3}^{2-}$ by $45 \%(\mathrm{LP})$ and $45 \%(\mathrm{HP})$, but it increased DIC by $10 \%$ (LP) and $9 \%$ (HP), $\mathrm{HCO}_{3}^{-}$by $14 \%$ (LP) and $14 \%$ (HP), and $\mathrm{CO}_{2}$ by $139 \%$ (LP) and $134 \%$ (HP).

The growth of S. muticum cultured at different $p \mathrm{CO}_{2}$ and $\mathrm{P}$ conditions was recorded (Fig. 1). $p \mathrm{CO}_{2}$ and $\mathrm{P}$ had an interactive effect on the relative growth rate of $S$. muticum (ANOVA, $F=5.776, \mathrm{~d} f=1,8, P=0.043)$, and each factor had a

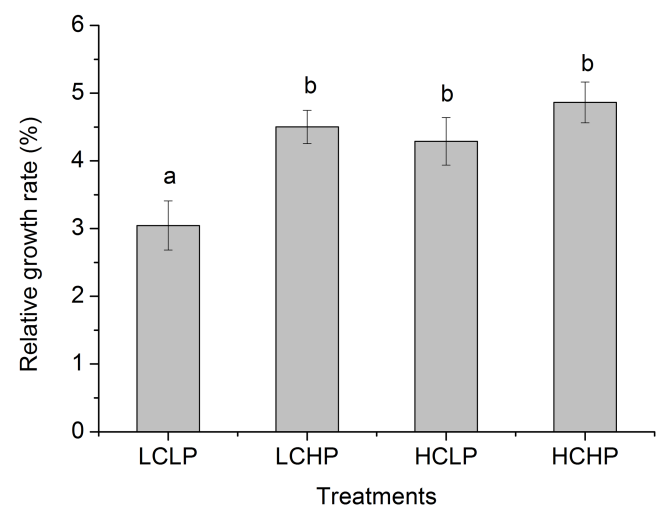

Figure 1. Relative growth rate (RGR) of $S$. muticum grown at different $p \mathrm{CO}_{2}$ and $\mathrm{P}$ conditions for 13 days. Data are reported as means $\pm \mathrm{SD}(n=3)$. LCLP is the low $p \mathrm{CO}_{2}$ and low $\mathrm{P}$ condition, LCHP is the low $p \mathrm{CO}_{2}$ and high $\mathrm{P}$ condition, HCLP is the high $p \mathrm{CO}_{2}$ and low $\mathrm{P}$ condition, and $\mathrm{HCHP}$ is the high $p \mathrm{CO}_{2}$ and high $\mathrm{P}$ condition. Different letters above the error bars indicate significant differences between treatments $(P<0.05)$.

main effect (ANOVA, $F=19.145, \mathrm{~d} f=1,8, P=0.002$ for $p \mathrm{CO}_{2}$; ANOVA, $F=30.592, \mathrm{~d} f=1,8, P=0.001$ for $\mathrm{P}$ ). A post hoc Tukey's HSD comparison $(P=0.05)$ showed that the higher levels of $p \mathrm{CO}_{2}$ and higher $\mathrm{P}$ alone increased the relative growth rate by 41 and $48 \%$, respectively, compared to the relative growth rate $(3.1 \pm 0.4 \%)$ at lower $p \mathrm{CO}_{2}$ and lower $\mathrm{P}$. The combination of the higher $p \mathrm{CO}_{2}$ and higher $\mathrm{P}$ levels did not enhance the relative growth rate as much as the sum of the higher $p \mathrm{CO}_{2}$ alone plus the higher $\mathrm{P}$ alone, with an increase of $59.66 \%$. Although the higher P level increased the relative growth rate at lower $p \mathrm{CO}_{2}$, it did not affect the relative growth rate at higher $p \mathrm{CO}_{2}$.

In terms of the net photosynthetic rate (Fig. 2), both $p \mathrm{CO}_{2}$ (ANOVA, $F=26.556, \mathrm{~d} f=1,8, P=0.001$ ) and $\mathrm{P}$ had main effects (ANOVA, $F=38.963, \mathrm{~d} f=1,8, P<0.001$ ). A post hoc Tukey's HSD comparison $(P=0.05)$ showed that the higher $p \mathrm{CO}_{2}$ level increased the net photosynthetic rates by 46 and $24 \%$ at lower $\mathrm{P}$ and higher P, respectively. The higher $\mathrm{P}$ level increased the net photosynthetic rates by 55 and $31 \%$ at lower $p \mathrm{CO}_{2}$ and higher $p \mathrm{CO}_{2}$, respectively. The difference in the net photosynthetic rate between LCHP and HCLP was statistically insignificant.

The carbon-saturating maximum photosynthetic rate $\left(V_{\max }\right)$ and the half saturation constant $\left(K_{0.5}\right)$ obtained from the photosynthesis versus DIC curves (Fig. 3) are shown in Table 2. The $p \mathrm{CO}_{2}$ and $\mathrm{P}$ had an interactive effect on the $V_{\max }$ of $S$. muticum (ANOVA, $F=10.095, \mathrm{~d} f=1,8$, $P=0.013$ ), and each factor had a main effect (ANOVA, $F=31.402, \mathrm{~d} f=1,8, P=0.001$ for $p \mathrm{CO}_{2}$; ANOVA, $F=$ $105.116, \mathrm{~d} f=1,8, P<0.001$ for $\mathrm{P})$. A post hoc Tukey's HSD comparison $(P=0.05)$ showed that the higher $p \mathrm{CO}_{2}$ level increased the $V_{\max }$ by $42 \%$ at lower P, while the increase at higher $\mathrm{P}$ was statistically insignificant. The higher 
Table 1. Parameters of the seawater carbonate system at different $\mathrm{CO}_{2}$ and phosphate conditions. Measurements and estimation of the parameters are described in the "Materials and methods" section. Data are reported as means $\pm \mathrm{SD}(n=3)$. LCLP is the low $p \mathrm{CO}{ }_{2}$ and low $\mathrm{P}$ condition, $\mathrm{LCHP}$ is the low $p \mathrm{CO}_{2}$ and high $\mathrm{P}$ condition, $\mathrm{HCLP}$ is the high $p \mathrm{CO}_{2}$ and low $\mathrm{P}$ condition, and $\mathrm{HCHP}$ is the high $p C \mathrm{C}_{2}$ and $\mathrm{P}$ condition. DIC is dissolved inorganic carbon, and TA is total alkalinity.

\begin{tabular}{lrrrrrrr}
\hline Treatment & $\mathrm{pH}$ & $\begin{array}{r}p \mathrm{CO}_{2} \\
(\mu \mathrm{atm})\end{array}$ & $\begin{array}{r}\mathrm{HCO}_{3}^{-} \\
\left.(\mu \mathrm{mol} \mathrm{kg})^{-1}\right)\end{array}$ & $\begin{array}{r}\mathrm{CO}_{3}^{2-} \\
\left(\mu \mathrm{mol} \mathrm{kg}{ }^{-1}\right)\end{array}$ & $\begin{array}{r}\mathrm{CO}_{2} \\
\left(\mu \mathrm{mol} \mathrm{kg}^{-1}\right)\end{array}$ & $\begin{array}{r}\mathrm{DIC} \\
\left(\mu \mathrm{mol} \mathrm{kg}{ }^{-1}\right)\end{array}$ & $\begin{array}{r}\mathrm{TA} \\
\left(\mu \mathrm{mol} \mathrm{kg}{ }^{-1}\right)\end{array}$ \\
\hline LCLP & $8.07 \pm 0.02^{\mathrm{b}}$ & $426.9 \pm 31.1^{\mathrm{a}}$ & $2000.2 \pm 51.7^{\mathrm{a}}$ & $200.9 \pm 5.8^{\mathrm{b}}$ & $14.2 \pm 1.0^{\mathrm{a}}$ & $2215.3 \pm 49.7^{\mathrm{a}}$ & $2475.2 \pm 44.2$ \\
LCHP & $8.07 \pm 0.02^{\mathrm{b}}$ & $423.9 \pm 21.1^{\mathrm{a}}$ & $1987.6 \pm 10.9^{\mathrm{a}}$ & $199.8 \pm 11.4^{\mathrm{b}}$ & $14.1 \pm 0.7^{\mathrm{a}}$ & $2201.5 \pm 19.3^{\mathrm{a}}$ & $2504.7 \pm 33.8$ \\
HCLP & $7.76 \pm 0.02^{\mathrm{a}}$ & $1017.2 \pm 83.2^{\mathrm{b}}$ & $2282.5 \pm 27.6^{\mathrm{b}}$ & $110.0 \pm 10.0^{\mathrm{a}}$ & $34.0 \pm 2.9^{\mathrm{b}}$ & $2426.5 \pm 32.5^{\mathrm{b}}$ & $2541.5 \pm 44.2$ \\
HCHP & $7.76 \pm 0.02^{\mathrm{a}}$ & $992.2 \pm 44.9^{\mathrm{b}}$ & $2261.8 \pm 35.9^{\mathrm{b}}$ & $110.5 \pm 5.9^{\mathrm{a}}$ & $33.1 \pm 1.5^{\mathrm{b}}$ & $2405.4 \pm 39.4^{\mathrm{b}}$ & $2563.6 \pm 44.2$ \\
\hline
\end{tabular}

a, b Different superscript letters indicate significant differences in one parameter between treatments $(P<0.05)$.

Table 2. The carbon-saturating maximum photosynthetic rate $\left(V_{\max }, \mu \mathrm{mol} \mathrm{O}_{2} \mathrm{~g}^{-1} \mathrm{FW} \mathrm{h}^{-1}\right)$ and half saturation constant $\left(K_{0.5}, \mathrm{mM}\right)$ for S. muticum cultured under different $p \mathrm{CO}_{2}$ and $\mathrm{P}$ conditions for 13 days.

\begin{tabular}{rrrrr}
\hline & LCLP & LCHP & HCLP & HCHP \\
\hline$V_{\max }$ & $57.00 \pm 2.88^{\mathrm{a}}$ & $93.99 \pm 0.98^{\mathrm{c}}$ & $81.18 \pm 5.94^{\mathrm{b}}$ & $100.67 \pm 6.81^{\mathrm{c}}$ \\
$K_{0.5}$ & $0.21 \pm 0.02^{\mathrm{a}}$ & $0.14 \pm 0.05^{\mathrm{a}}$ & $0.42 \pm 0.08^{\mathrm{b}}$ & $0.19 \pm 0.05^{\mathrm{a}}$ \\
\hline
\end{tabular}

a, b, c Different superscript letters indicate significant differences in one parameter between treatments $(P<0.05)$.

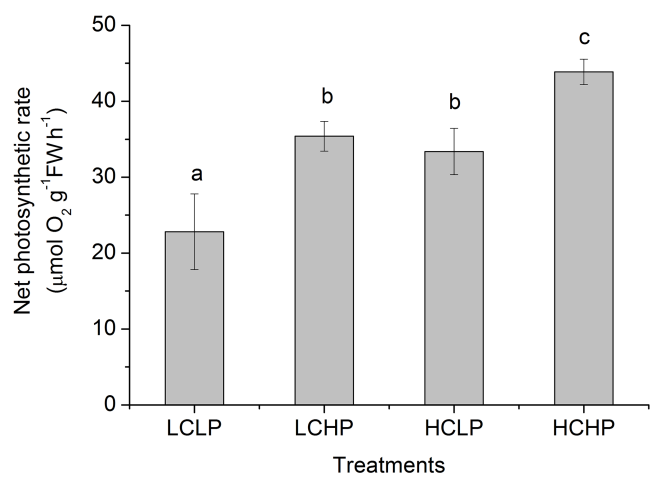

Figure 2. Net photosynthetic rate (NPR) of S. muticum after being grown at different $p \mathrm{CO}_{2}$ and $\mathrm{P}$ conditions for 13 days. Data are reported as means $\pm \mathrm{SD}(n=3)$. LCLP is the low $p \mathrm{CO}_{2}$ and low $\mathrm{P}$ condition, LCHP is the low $p \mathrm{CO}_{2}$ and high $\mathrm{P}$ condition, HCLP is the high $p \mathrm{CO}_{2}$ and low $\mathrm{P}$ condition, and HCHP is the high $p \mathrm{CO}_{2}$ and high $\mathrm{P}$ condition. Different letters above the error bars indicate significant differences between treatments $(P<0.05)$.

P level increased the $V_{\max }$ at the conditions of both lower $p \mathrm{CO}_{2}(65 \%)$ and higher $p \mathrm{CO}_{2}(24 \%)$ with a larger promoting effect at lower $p \mathrm{CO}_{2}$.

$p \mathrm{CO}_{2}$ and $\mathrm{P}$ interacted on the $K_{0.5}$ of $S$. muticum (ANOVA, $F=5.928, \mathrm{~d} f=1,8, P=0.041$ ), and each factor had a main effect (ANOVA, $F=14.713, \mathrm{~d} f=1,8$, $P=0.005$ for $p \mathrm{CO}_{2}$; ANOVA, $F=20.857, \mathrm{~d} f=1,8, P=$ 0.002 for $\mathrm{P})$. A post hoc Tukey's HSD comparison $(P=$ $0.05)$ showed that the higher $p \mathrm{CO}_{2}$ level increased the $K_{0.5}$ by $98 \%$ at lower P but did not affect it at higher P. In con-

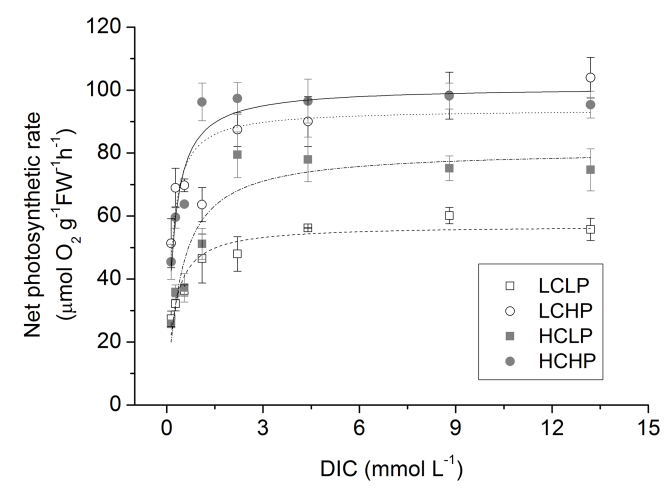

Figure 3. The photosynthesis versus DIC curves of $S$. muticum after being cultured under $p \mathrm{CO}_{2}$ and $\mathrm{P}$ conditions for 13 days. Data are reported as means $\pm \mathrm{SD}(n=3)$. LCLP is the low $p \mathrm{CO}_{2}$ and low $\mathrm{P}$ condition, LCHP is the low $p \mathrm{CO}_{2}$ and high $\mathrm{P}$ condition, HCLP is the high $p \mathrm{CO}_{2}$ and low $\mathrm{P}$ condition, and $\mathrm{HCHP}$ is the high $p \mathrm{CO}_{2}$ and high $\mathrm{P}$ condition. DIC is dissolved inorganic carbon.

trast, the higher $\mathrm{P}$ level decreased the $K_{0.5}$ by $55 \%$ at higher $p \mathrm{CO}_{2}$ and the negative effect of the higher $\mathrm{P}$ level at lower $p \mathrm{CO}_{2}$ was insignificant.

The amounts of the photosynthetic pigment $\mathrm{Chl} a$ under various treatments were also estimated (Fig. 4). $p \mathrm{CO}_{2}$ and $\mathrm{P}$ had an interactive effect on the Chl $a$ content (ANOVA, $F=8.184, \mathrm{~d} f=1,8, P=0.021$ ), and $\mathrm{P}$ had a main effect (ANOVA, $F=22.828$, d $f=1,8, P=0.001$ ), while $p \mathrm{CO}_{2}$ did not affect it (ANOVA, $F=0.676, \mathrm{~d} f=$ $1,8, P=0.435$ ). A post hoc Tukey's HSD comparison 


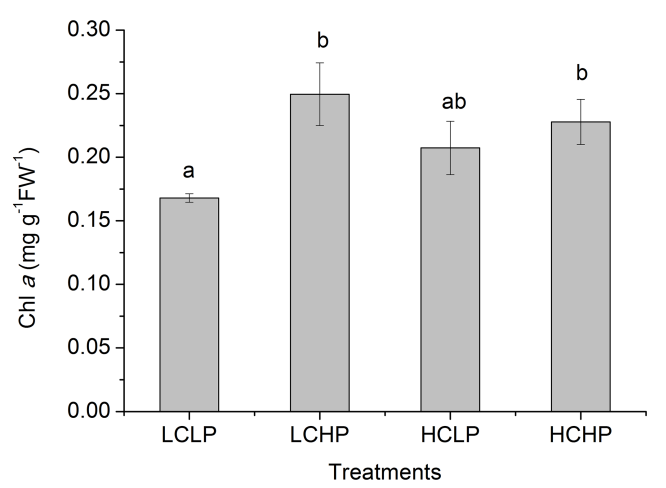

Figure 4. Chl $a$ content of $S$. muticum after being grown at different $p \mathrm{CO}_{2}$ and $\mathrm{P}$ conditions for 13 days. Data are reported as means $\pm \mathrm{SD}(n=3)$. LCLP is the low $p \mathrm{CO}_{2}$ and low $\mathrm{P}$ condition, LCHP is the low $p \mathrm{CO}_{2}$ and high $\mathrm{P}$ condition, HCLP is the high $p \mathrm{CO}_{2}$ and low $\mathrm{P}$ condition, and $\mathrm{HCHP}$ is the high $p \mathrm{CO}_{2}$ and high $\mathrm{P}$ condition. Different letters above the error bars indicate significant differences between treatments $(P<0.05)$.

$(P=0.05)$ showed that the higher $\mathrm{P}$ level increased the Chl $a$ content from $0.17 \pm 0.00$ to $0.25 \pm 0.02 \mathrm{mg} \mathrm{g}^{-1} \mathrm{FW}$ at lower $p \mathrm{CO}_{2}$, whereas the difference in the Chl $a$ content between HCLP $\left(0.21 \pm 0.02 \mathrm{mg} \mathrm{g}^{-1} \mathrm{FW}\right)$ and HCHP $\left(0.23 \pm 0.02 \mathrm{mg} \mathrm{g}^{-1} \mathrm{FW}\right)$ was not statistically significant.

To assess the effects of ocean acidification and $\mathrm{P}$ enrichment on the nitrogen assimilation in S. muticum, the nitrate uptake rate under various $p \mathrm{CO}_{2}$ and $\mathrm{P}$ treatments was investigated (Fig. 5). Both $p \mathrm{CO}_{2}$ (ANOVA, $F=139.916$, $\mathrm{d} f=1,8, P<0.001$ ) and $\mathrm{P}$ (ANOVA, $F=43.923, \mathrm{~d} f=1$, $8, P<0.001$ ) had main effects on the nitrate uptake rate of S. muticum. The nitrate uptake rates at lower $p \mathrm{CO}_{2}$ were $0.18 \pm 0.01$ (LP) and $0.25 \pm 0.03 \mu \mathrm{mol} \mathrm{NO} \mathrm{Ng}^{-1} \mathrm{FW} \mathrm{h}^{-1}$ (HP), respectively. A post hoc Tukey's HSD comparison $(P=0.05)$ showed that the higher $p \mathrm{CO}_{2}$ level increased the nitrate uptake rate to $0.31 \pm 0.02 \mu \mathrm{mol} \mathrm{NO} \mathrm{g}^{-} \mathrm{g}^{-1} \mathrm{FW} \mathrm{h}^{-1}$ at lower $\mathrm{P}$ and to $0.39 \pm 0.01 \mu \mathrm{mol} \mathrm{NO} \mathrm{g}^{-} \mathrm{g}^{-1} \mathrm{FW} \mathrm{h}^{-1}$ at higher $\mathrm{P}$, compared to the rates at lower $p \mathrm{CO}_{2}$. The higher $\mathrm{P}$ level also increased the nitrate uptake rate by $36 \%$ at lower $p \mathrm{CO}_{2}$ and by $28 \%$ at higher $p \mathrm{CO}_{2}$, compared to the rates at lower P.

Apart from nitrate uptake, the NRA of $S$. muticum under various $p \mathrm{CO}_{2}$ and $\mathrm{P}$ treatments was also detected (Fig. 6). $p \mathrm{CO}_{2}$ and $\mathrm{P}$ interacted on the NRA of $S$. muticum (ANOVA, $F=28.435, \mathrm{~d} f=1,8, P=0.001$ ), and $p \mathrm{CO}_{2}$ had a main effect (ANOVA, $F=59.038$, $\mathrm{d} f=1,8, P<0.001)$. The NRAs at lower $p \mathrm{CO}_{2}$ were $0.10 \pm 0.01$ (LP) and $0.14 \pm 0.02 \mu \mathrm{mol} \mathrm{NO} \mathrm{N}^{-} \mathrm{g}^{-1} \mathrm{FW} \mathrm{h}^{-1}$ (HP), respectively. The higher $p \mathrm{CO}_{2}$ level increased it to $0.19 \pm 0.00 \mu \mathrm{mol} \mathrm{NO}_{2}^{-} \mathrm{g}^{-1} \mathrm{FWh}^{-1}$ at lower $\mathrm{P}$ and to $0.15 \pm 0.02 \mu \mathrm{mol} \mathrm{NO} \mathrm{N}_{2}^{-} \mathrm{g}^{-1} \mathrm{FW} \mathrm{h}^{-1}$ at higher P. The higher $\mathrm{P}$ level increased the NRA by $39 \%$ at lower $p \mathrm{CO}_{2}$; however, it decreased the NRA by $18 \%$ at higher $p \mathrm{CO}_{2}$.

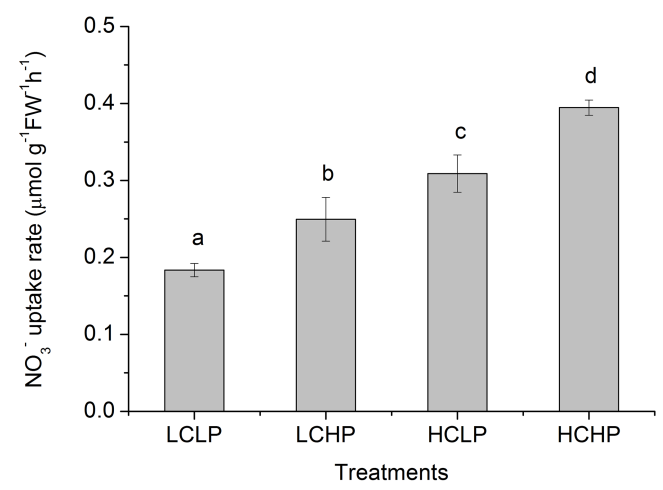

Figure 5. Nitrate uptake rate of $S$. muticum after being grown at different $p \mathrm{CO}_{2}$ and $\mathrm{P}$ conditions for 13 days. Data are reported as means $\pm \mathrm{SD}(n=3)$. LCLP is the low $p \mathrm{CO}_{2}$ and low $\mathrm{P}$ condition, LCHP is the low $p \mathrm{CO}_{2}$ and high $\mathrm{P}$ condition, HCLP is the high $p \mathrm{CO}_{2}$ and low $\mathrm{P}$ condition, and HCHP is the high $p \mathrm{CO}_{2}$ and high $\mathrm{P}$ condition. Different letters above the error bars indicate significant differences between treatments $(P<0.05)$.

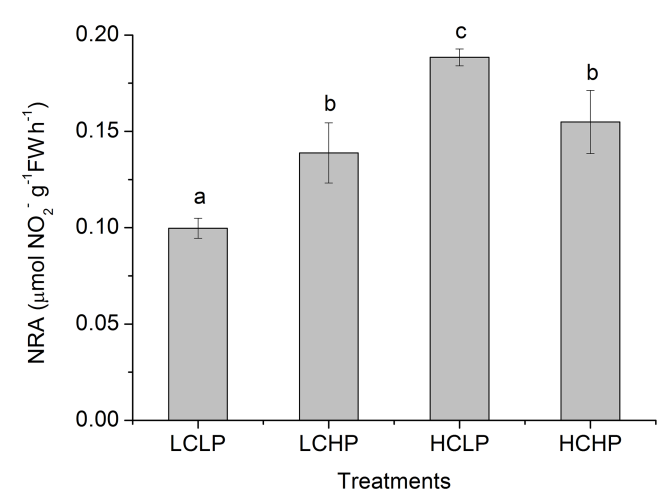

Figure 6. Nitrate reductase activity (NRA) of $S$. muticum after being grown at different $p \mathrm{CO}_{2}$ and $\mathrm{P}$ conditions for 13 days. Data are reported as means means $\pm \mathrm{SD}(n=3)$. LCLP is the low $p \mathrm{CO}_{2}$ and low $\mathrm{P}$ condition, LCHP is the low $p \mathrm{CO}_{2}$ and high $\mathrm{P}$ condition, HCLP is the high $p \mathrm{CO}_{2}$ and low $\mathrm{P}$ condition, and HCHP is the high $p \mathrm{CO}_{2}$ and high $\mathrm{P}$ condition. Different letters above the error bars indicate significant differences between treatments $(P<0.05)$.

The soluble carbohydrates (Fig. 7a) and protein (Fig. 7b) were estimated to understand the effects of ocean acidification and $\mathrm{P}$ enrichment on the products of carbon and nitrogen assimilation in $S$. muticum. $p \mathrm{CO}_{2}$ and $\mathrm{P}$ had an interactive effect on the soluble carbohydrates (ANOVA, $F=$ 18.294, $\mathrm{d} f=1,8, P=0.003$ ), and $\mathrm{P}$ had a main effect (ANOVA, $F=23.129$, d $f=1,8, P=0.001$ ). The higher $\mathrm{P}$ level increased the soluble carbohydrates from $25.40 \pm 1.66$ to $41.10 \pm 1.74 \mathrm{mg} \mathrm{g}^{-1} \mathrm{FW}$ at lower $p \mathrm{CO}_{2}$ but did not alter them at higher $p \mathrm{CO}_{2}$. The higher $p \mathrm{CO}_{2}$ level increased the soluble carbohydrates to $33.72 \pm 3.31 \mathrm{mg} \mathrm{g}^{-1} \mathrm{FW}$ at lower $\mathrm{P}$, while the decrease of soluble carbohydrates caused by the higher $p \mathrm{CO}_{2}$ level was not statistically significant at higher $\mathrm{P}$. 

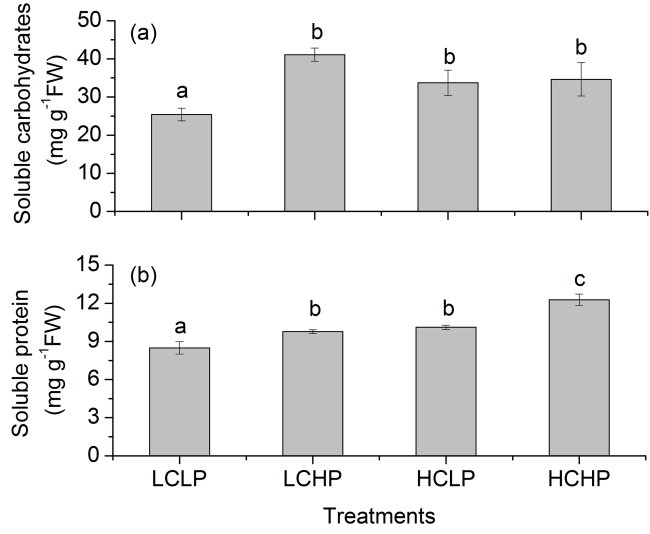

Figure 7. The contents of soluble carbohydrates (a) and protein (b) of $S$. muticum after being grown at different $p \mathrm{CO}_{2}$ and $\mathrm{P}$ conditions for 13 days. Data are reported as means $\pm \mathrm{SD}(n=3)$. LCLP is the low $p \mathrm{CO}_{2}$ and low $\mathrm{P}$ condition, LCHP is the low $p \mathrm{CO}_{2}$ and high $\mathrm{P}$ condition, HCLP is the high $p \mathrm{CO}_{2}$ and low $\mathrm{P}$ condition, and HCHP is the high $p \mathrm{CO}_{2}$ and high $\mathrm{P}$ condition. Different letters above the error bars indicate significant differences between treatments $(P<$ $0.05)$.

Both $p \mathrm{CO}_{2}$ (ANOVA, $F=106.663, \mathrm{~d} f=1,8, P<$ 0.001 ) and $\mathrm{P}$ (ANOVA, $F=75.003, \mathrm{~d} f=1,8, P<0.001$ ) had main effects on the soluble protein of $S$. muticum, and an interactive effect of the two factors was not detected (ANOVA, $F=4.961, \mathrm{~d} f=1,8, P=0.057$ ). The soluble protein contents at lower $p \mathrm{CO}_{2}$ were $8.49 \pm 0.49$ (LP) and $9.77 \pm 0.14 \mathrm{mg} \mathrm{g}^{-1} \mathrm{FW}(\mathrm{HP})$, respectively. The higher $p \mathrm{CO}_{2}$ level increased it to $10.11 \pm 0.16 \mathrm{mg} \mathrm{g}^{-1} \mathrm{FW}$ at lower $\mathrm{P}$ and to $12.28 \pm 0.44 \mathrm{mg} \mathrm{g}^{-1} \mathrm{FW}$ at higher $\mathrm{P}$. The higher $\mathrm{P}$ level also increased the soluble protein contents by $15 \%$ at lower $p \mathrm{CO}_{2}$ and by $21 \%$ at higher $p \mathrm{CO}_{2}$.

Finally, the effects of ocean acidification and $\mathrm{P}$ enrichment on the dark respiration rate of $S$. muticum were investigated (Fig. 8). $p \mathrm{CO}_{2}$ and $\mathrm{P}$ had an interactive effect on the dark respiration rate (ANOVA, $F=19.584$, $\mathrm{d} f=1,8, P=0.002)$, and each factor had a main effect (ANOVA, $F=6.428, \mathrm{~d} f=1,8, P=0.035$ for $p \mathrm{CO}_{2}$; ANOVA, $F=6.754, \mathrm{~d} f=1,8, P=0.032$ for $\mathrm{P})$. The higher $p \mathrm{CO}_{2}$ level increased the dark respiration rate from $14.21 \pm 1.94$ to $21.24 \pm 1.28 \mu \mathrm{mol} \mathrm{O}_{2} \mathrm{~g}^{-1} \mathrm{FW} \mathrm{h}^{-1}$ at higher $\mathrm{P}$ but did not affect it at lower P. Likewise, the higher $\mathrm{P}$ level increased the respiration rate from $14.15 \pm 0.65$ to $21.24 \pm 1.28 \mu \mathrm{mol} \mathrm{O}_{2} \mathrm{~g}^{-1} \mathrm{FW} \mathrm{h}^{-1}$ at higher $p \mathrm{CO}_{2}$ but did not change it at lower $p \mathrm{CO}_{2}$.

\section{Discussion}

\subsection{Effects of $p \mathrm{CO}_{2}$ and $\mathrm{P}$ on carbon assimilation}

The higher $p \mathrm{CO}_{2}$ level increased the net photosynthetic rate in $S$. muticum at lower P in the present study. Although the

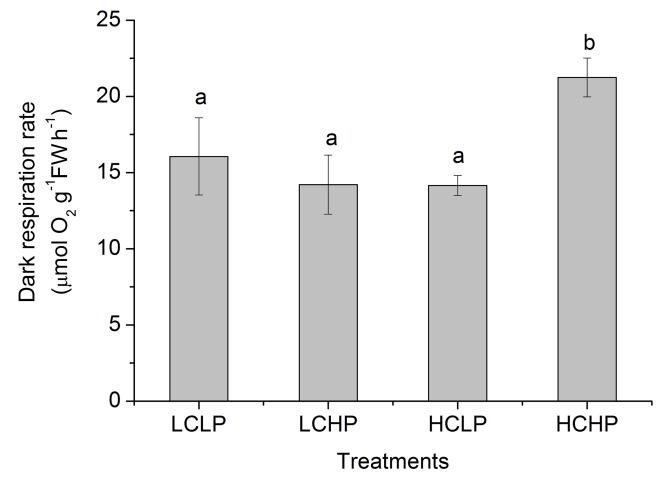

Figure 8. Dark respiration rate of $S$. muticum after being grown at different $p \mathrm{CO}_{2}$ and $\mathrm{P}$ conditions for 13 days. Data are reported as means $\pm \mathrm{SD}(n=3)$. LCLP is the low $p \mathrm{CO}_{2}$ and low $\mathrm{P}$ condition, LCHP is the low $p \mathrm{CO}_{2}$ and high $\mathrm{P}$ condition, HCLP is the high $p \mathrm{CO}_{2}$ and low $\mathrm{P}$ condition, and $\mathrm{HCHP}$ is the high $p \mathrm{CO}_{2}$ and high $\mathrm{P}$ condition. Different letters above the error bars indicate significant differences between treatments $(P<0.05)$.

dissolved inorganic carbon in seawater is around $2 \mathrm{mM}$, the dominant form is $\mathrm{HCO}_{3}^{-}$with $\mathrm{CO}_{2}$ typically accounting for less than $1 \%$ (Dickson, 2010). In addition, $\mathrm{CO}_{2}$ in seawater diffuses $\sim 8000$ times more slowly than in air (Gao and Campbell, 2014). Furthermore, marine macroalgae have high $K_{0.5}$ values (40-70 $\mu \mathrm{M} \mathrm{CO}_{2}$ ) for Rubisco, the carbon assimilating enzyme (Ji et al., 2016). The evidence above indicates that the $\mathrm{CO}_{2}$ in seawater should be carbon limited for marine macroalgae. The promoting effect of elevated $\mathrm{CO}_{2}$ on photosynthesis was also reported in other macroalgae species, such as the green algae Ulva linza (Gao et al., 1999), the red algae Pyropia haitanensis (Zou and Gao, 2002), and the brown algae Petalonia binghamiae (Zou and Gao, 2010). The higher $p \mathrm{CO}_{2}$ level increased $K_{0.5}$ of $S$. muticum at lower $\mathrm{P}$ in the present study, which indicates that a plant grown under conditions of higher $p \mathrm{CO}_{2}$ reduces its photosynthetic affinity for DIC. This phenomenon is commonly found in both microalgae and macroalgae (Gao and Campbell, 2014; Ji et al., 2016; Wu et al., 2008) and is considered a sign of downregulated CCMs at high $\mathrm{CO}_{2}$ conditions (Gao and Campbell, 2014). However, this decrease of photosynthetic affinity for DIC did not lead to reduced photosynthesis in S. muticum compared to that at the lower $p \mathrm{CO}_{2}$ in the present study, mainly because of increased $\mathrm{CO}_{2}$ availability for Rubisco and depressed photorespiration at the elevated ratio of $\mathrm{CO}_{2}$ to $\mathrm{O}_{2}$, which has been confirmed in the red seaweed Lomentaria articulata (Kübler et al., 1999).

The higher P level also increased the net photosynthetic rate of $S$. muticum in the present study, which can be partially explained by the decreased $K_{0.5}$ at higher P. The decreased $K_{0.5}$ is an indication of increased photosynthetic carbon-use capability. Phosphorus is a key macronutrient component for organisms, and high levels of $\mathrm{P}$ availability are not only essential for chloroplast DNA and RNA syn- 
thesis (Vered and Shlomit, 2008), but are also required for various chloroplast functions referring to the phosphorylation of photosynthetic proteins, the synthesis of phospholipids, and the generation of adenosine triphosphate (ATP; Zer and Ohad, 2003). Therefore, high P levels could speed up the transport of $\mathrm{Ci}$ from media to the site of Rubisco by supplying necessary energy. In addition, $\mathrm{P}$ enrichment can increase both the activity and the amount of Rubisco (Lauer et al., 1989). Phosphorus, with low concentrations in seawater, is generally considered to be limiting for marine primary producers (Elser et al., 2007; Howarth, 1988; Müller and Mitrovic, 2015). Therefore, adding extra phosphorus to natural seawater can stimulate the photosynthesis of algae. For instance, the midday (12:00) photosynthetic rates increased from 1.3 to $2.3 \mathrm{mg} \mathrm{C} \mathrm{g}^{-1} \mathrm{DW} \mathrm{h}^{-1}$ for $S$. natans and from 0.9 to $2.1 \mathrm{mg} \mathrm{Cg}^{-1} \mathrm{DW} \mathrm{h}^{-1}$ for $S$. fluitans when $0.2 \mathrm{mM} \mathrm{P}$ was added (Lapointe, 1986). In the present study, the addition of $40 \mu \mathrm{mol} \mathrm{P}$ also resulted in a nearly 2 -fold increase of the net photosynthetic rate and the $V_{\max }$, which suggests the importance of $\mathrm{P}$ in the photosynthesis of this alga. In addition, the higher $\mathrm{P}$ level promoted the synthesis of Chl $a$ at the condition of lower $p \mathrm{CO}_{2}$, which may also contribute to the increased net photosynthetic rate in S. muticum at higher P. Although $\mathrm{P}$ is not a component constituting $\mathrm{Chl} a$, a higher $\mathrm{P}$ supply may stimulate the content of Chl $a$ synthesis-related enzymes and thus the production of Chl $a$. The positive effect of $\mathrm{P}$ on Chl $a$ was also reported in S. thunbergii (Nakahara, 1990). On the other hand, the higher $P$ level did not increase the $\mathrm{Chl} a$ content at higher $p \mathrm{CO}_{2}$ in the present study. A possible reason is that there is more ATP available at higher $p \mathrm{CO}_{2}$ due to the downregulation of CCMs, and thus there is no need to synthesize more $\mathrm{Chl} a$ to capture more light for cells, as excessive energy can harm the photosynthesis and growth of algae (Gao et al., 2012; Xu and Gao, 2012).

\subsection{Effect of $p \mathrm{CO}_{2}$ and $\mathrm{P}$ on nitrogen assimilation}

The higher $p \mathrm{CO}_{2}$ level noticeably enhanced the nitrate uptake rate in $S$. muticum regardless of $\mathrm{P}$ concentration in the present study. This could be attributed to the increased NRA at the condition of higher $p \mathrm{CO}_{2}$. The enhanced NRA at the conditions of high $\mathrm{CO}_{2}$ was also reported in $U$. rigida (Gordillo et al., 2001), Hizikia fusiforme (Zou, 2005), P. haitanensis (Liu and Zou, 2015), and Corallina officinalis (Hofmann et al., 2013), as well as in the higher plants Plantago major (Fonseca et al., 1997) and tomatoes (Yelle et al., 1987). Taken together, these findings indicate that the response of NRA in plants to elevated $\mathrm{CO}_{2}$ may be homogeneous.

The higher P level also enhanced the nitrate uptake in $S$. muticum regardless of the $p \mathrm{CO}_{2}$ level, which could be partially due to the increased NRA at higher P. This is very evident at lower $p \mathrm{CO}_{2}$. However, the higher $\mathrm{P}$ level decreased the NRA at higher $p \mathrm{CO}_{2}$, which did not lead to reduced nitrate uptake. This indicates that there should be other mechanisms to account for the promoting effect of the higher $\mathrm{P}$ level on the nitrate uptake. One possible mechanism is the higher P level increasing the availability of ATP required for the active uptake of nitrate across the plasma membrane. The phenomenon of ATP concentration increasing with P level has been found in higher plants (Olivera et al., 2004; Rychter et al., 2006). Apart from S. muticum, the positive effect of a higher P level on nitrate uptake was also reported in the red macroalgae Gracilaria lemaneiformis (Xu et al., 2010) and the higher plant Phaseolus vulgaris (Gniazdowska and Rychter, 2000). The increased nitrate uptake, NRA, and soluble protein at higher $\mathrm{P}$ in the present study suggest that high $\mathrm{P}$ availability promoted nitrogen assimilation in $S . \mathbf{m и -}$ ticum. It is worth noting that the nitrate uptake rates were commonly higher than the corresponding reduction rates of $\mathrm{NO}_{3}^{-}$to nitrite $\mathrm{NO}_{2}^{-}$by nitrate reductase in the present study, which might be due to the intercellular nitrate storage (Collos, 1982; Lartigue and Sherman, 2005) and the underestimation of RNA measured by the in situ assay (Lartigue and Sherman, 2002). The higher P level increased the nitrate uptake rate and soluble protein at both lower $p \mathrm{CO}_{2}$ and higher $p \mathrm{CO}_{2}$, but it only increased the NRA in S. muticum at lower $p \mathrm{CO}_{2}$ in the present study. Surprisingly, it decreased the NRA at higher $p \mathrm{CO}_{2}$. There may be more than one reason related to interaction of $p \mathrm{CO}_{2}$ and $\mathrm{P}$. High $p \mathrm{CO}_{2}$, on the one hand, could enhance photosynthetic carbon fixation and thus growth by supplying sufficient $\mathrm{CO}_{2}$. On the other hand, it also results in the decrease of $\mathrm{pH}$ and the increase of seawater acidity, which can disturb the acid-base balance on the cell surface of algae (Flynn et al., 2012). Algae may accordingly allocate additional energy to act against the acid-base perturbation in some way. This hypothesis is supported by increased respiration at higher $p \mathrm{CO}_{2}$ and higher $\mathrm{P}$ in the present study. The increased soluble protein and decreased NRA at higher $p \mathrm{CO}_{2}$ and higher $\mathrm{P}$ suggest that some $\mathrm{H}^{+}$transport-related protein, such as plasma membrane $\mathrm{H}^{+}$ATPase, might be synthesized to counteract the acid-base perturbation caused by increased $p \mathrm{CO}_{2}$ and $\mathrm{H}^{+}$. The additional production of an $\mathrm{H}^{+}$transport-related protein, like plasma membrane $\mathrm{H}^{+}$-ATPase, could competitively decrease the synthesis of nitrate reductase. This hypothesis needs further experimental evidence to confirm, even though it could explain the results in the present study.

\subsection{Connection between carbon and nitrogen assimilation}

The increased net photosynthetic rate at higher $p \mathrm{CO}_{2}$ and higher $\mathrm{P}$ did not result in higher soluble carbohydrates compared to higher $p \mathrm{CO}_{2}$ and lower P. The additional ATP produced by photosynthetic electron transport higher $p \mathrm{CO}_{2}$ and higher $\mathrm{P}$ may be drawn to nitrogen assimilation as more soluble protein was synthesized at higher $p \mathrm{CO}_{2}$ and higher $\mathrm{P}$. The additional energy allocation to protein synthesis, possibly an $\mathrm{H}^{+}$transport-related protein, to maintain the balance of acidbase hindered the increase of growth, which may be the rea- 
son that the higher $\mathrm{P}$ increased the net photosynthetic rate but not the growth rate at higher $p \mathrm{CO}_{2}$. Although synthesized protein can also contribute to the increase of thalli weight, it is not as energy-effective as carbohydrates (Norici et al., 2011; Raven, 1982). It seems that S. muticum tends to maintain a steady state in vivo, even if it can sacrifice growth to some extent, considering that the regulation of the intracellular acid-base balance is crucial for organismal homoeostasis (Flynn et al., 2012; Smith and Raven, 1979). The increased respiration at $\mathrm{HC}$ was also demonstrated in G. lemaneiformis (Xu et al., 2010) and U. prolifera (Xu and Gao, 2012). The respiration at higher $p \mathrm{CO}_{2}$ and lower $\mathrm{P}$ did not increase compared to at lower $p \mathrm{CO}_{2}$ and lower $\mathrm{P}$ in the present study, suggesting that action against acid-base perturbation did not commence. The acid-base perturbation at higher $p \mathrm{CO}_{2}$ and lower $\mathrm{P}$ may lead to the decreased photosynthetic rate compared to that at lower $p \mathrm{CO}_{2}$ and lower P.

\section{Conclusion}

Our study, for the first time, demonstrates the combined effects of elevated $p \mathrm{CO}_{2}$ and $\mathrm{P}$ enrichment on the physiological traits of a golden alga, S. muticum. It suggests that the current ocean environment is both $\mathrm{CO}_{2}$ and $\mathrm{P}$ limited for the photosynthesis and growth of S. muticum. Therefore, future ocean acidification and eutrophication may promote the growth of S. muticum and thus the occurrence of golden tide events. S. muticum tends to maintain homoeostasis by taking advantage of phosphate enrichment at the cost of growth. Accordingly, the combination of ocean acidification and eutrophication may not boost golden tides further compared to ocean acidification or eutrophication alone.

\section{Data availability}

The data to this paper can be found in the Supplement.

\section{The Supplement related to this article is available online at doi:10.5194/bg-14-671-2017-supplement.}

Competing interests. The authors declare that they have no conflict of interest.

Acknowledgements. This study was supported by the National Natural Science Foundation of China (Nos. 41376129, 41476097 and 31270452), the Science Foundation of Huaihai Institute of Technology (Z2016007), the Public Science and Technology Research Funds Projects of Ocean (Nos. 201505022, 201405040 and 201305021), the earmarked fund for Modern Agro-industry Technology Research System in Shandong Province (SDAIT-26), and the Experimental Study Project on Ecological Simulation in Coastal Waters of Shandong Peninsula.

Edited by: T. Treude

Reviewed by: D. Campbell and two anonymous referees

\section{References}

Alvaro, I. and Mazal, H.: Growth, photosynthetic properties and Rubisco activities and amounts of marine macroalgae grown under current and elevated seawater $\mathrm{CO}_{2}$ concentrations, Glob. Change Biol., 30, 831-840, 2002.

Ang, P. O.: Phenology of Sargassum spp. in Tung Ping Chau Marine Park, Hong Kong SAR, China, J. Appl. Phycol., 18, 403-410, 2006.

Ashok-Kumar, N., Vanlalzarzova, B., Sridhar, S., and Baluswami, M.: Effect of liquid seaweed fertilizer of Sargassum wightii Grev. on the growth and biochemical content of green gram (Vigna radiata (L.) R. Wilczek), Recent Res. Sci. Technol., 4, 40-45, 2012.

Bradford, M. M.: A rapid and sensitive method for the quantitation of microgram quantities of protein utilizing the principle of protein-dye binding, Anal. Biochem., 72, 248-254, 1976.

Bricker, S. B., Longstaff, B., Dennison, W., Jones, A., Boicourt, K., Wicks, C., and Woerner, J.: Effects of nutrient enrichment in the nation's estuaries: a decade of change, Harmful Algae, 8, 21-32, 2008.

Caemmerer, S. V. and Farquhar, G. D.: Some relationships between the biochemistry of photosynthesis and the gas exchange of leaves, Planta, 153, 376-387, 1981.

Carpenter, S. R.: Submersed vegetation: an internal factor in lake ecosystem succession, Am. Nat., 118, 372-383, 1981.

Carpenter, S. R., Caraco, N. F., Correll, D. L., Howarth, R. W., Sharpley, A. N., and Smith, V. H.: Nonpoint pollution of surface waters with phosphorus and nitrogen, Ecol. Appl., 8, 559-568, 1998.

Cheang, C. C., Chu, K. H., Fujita, D., Yoshida, G., Hiraoka, M., Critchley, A., Choi, H. G., Duan, D., Serisawa, Y., and Ang, P. O.: Low genetic variability of Sargassum muticum (Phaeophyceae) revealed by a global analysis of native and introduced populations, J. Phycol., 46, 1063-1074, 2010.

Chen, B. and Zou, D.: Growth and photosynthetic activity of Sargassum henslowianum (Fucales, Phaeophyta) seedlings in responses to different light intensities, temperatures and $\mathrm{CO}_{2} \mathrm{lev}$ els under laboratory conditions, Mar. Biol. Res., 10, 1019-1026, 2014.

Collos, Y.: Transient situations in nitrate assimilation by marine diatoms. III. Short-term uncoupling of nitrate uptake and reduction, J. Exp. Mar. Bio. Ecol., 62, 285-295, 1982.

Corzo, A. and Niell, F. X.: Determination of nitrate reductase activity in Ulva rigida C. Agardh by the in situ method, J. Exp. Mar. Bio. Ecol., 146, 181-191, 1991.

Cruzrivera, E., Floresdíaz, M., and Hawkins, A.: A fish kill coincident with dense Sargassum accumulation in a tropical bay, Bull Mar. Sci., 91, 455-456, 2015.

Deng, M. D., Moureaux, T., Cherel, I., Boutin, J. P., and Caboche, M.: Effects of nitrogen metabolites on the regulation and cir- 
cadian expression of tobacco nitrate reductase, Plant Physiol. Biochem., 29, 239-247, 1991.

Dickson, A. G.: The carbon dioxide system in seawater: Equilibrium chemistry and measurements, in: Guide to best practices for ocean acidification research and data reporting, edited by: Riebesell, U., Fabry, V. J., Hansson, L., and Gattuso, J. P., Publications Office of the European Union, Luxembourg, 2010.

Elser, J. J., Bracken, M. E. S., Cleland, E. E., Gruner, D. S., Harpole, W. S., Hillebrand, H., Ngai, J. T., Seabloom, E. W., Shurin, J. B., and Smith, J. E.: Global analysis of nitrogen and phosphorus limitation of primary producers in freshwater, marine and terrestrial ecosystems, Ecol. Lett., 10, 1135-1142, 2007.

Fenoradosoa, T. A., Ali, G., Delattre, C., Laroche, C., Petit, E., Wadouachi, A., and Michaud, P.: Extraction and characterization of an alginate from the brown seaweed Sargassum turbinarioides Grunow, J. Appl. Phycol., 22, 131-137, 2010.

Flynn, K. J., Blackford, J. C., Baird, M. E., Raven, J. A., Clark, D. R., Beardall, J., Brownlee, C., Fabian, H., and Wheeler, G. L.: Changes in $\mathrm{pH}$ at the exterior surface of plankton with ocean acidification, Nat. Clim. Change, 2, 510-513, 2012.

Fonseca, F., Bowsher, C. G., and Stulen, I.: Impact of elevated atmospheric $\mathrm{CO}_{2}$ on nitrate reductase transcription and activity in leaves and roots of Plantago major, Physiol. Plantarum, 100, 940-948, 1997.

Gao, K. and Campbell, D. A.: Photophysiological responses of marine diatoms to elevated $\mathrm{CO}_{2}$ and decreased $\mathrm{pH}$ : a review, Funct. Plant Biol., 41, 449-459, 2014.

Gao, K., Yan, J., and Aruga, Y.: Relationship of $\mathrm{CO}_{2}$ concentrations to photosynthesis of intertidal macroalgae during emersion, Hydrobiologia, 398/399, 355-359, 1999.

Gao, K., Xu, J., Gao, G., Li, Y., Hutchins, D. A., Huang, B., Wang, L., Zheng, Y., Jin, P., and Cai, X.: Rising $\mathrm{CO}_{2}$ and increased light exposure synergistically reduce marine primary productivity, Nat. Clim. Change, 2, 519-523, 2012.

Gniazdowska, A. and Rychter, A. M.: Nitrate uptake by bean (Phaseolus vulgaris L.) roots under phosphate deficiency, Plant Soil, 226, 79-85, 2000.

González-López, N., Moure, A., and Domínguez, H.: Hydrothermal fractionation of Sargassum muticum biomass, J. Appl. Phycol., 24, 1569-1578, 2012.

Gordillo, F. J. L., Niell, F. X., and Figueroa, F. L.: Nonphotosynthetic enhancement of growth by high $\mathrm{CO}_{2}$ level in the nitrophilic seaweed Ulva rigida C. Agardh (Chlorophyta), Planta, 213, 64-70, 2001.

Hofmann, L., Straub, S., and Bischof, K.: Elevated $\mathrm{CO}_{2}$ levels affect the activity of nitrate reductase and carbonic anhydrase in the calcifying rhodophyte Corallina officinalis, J. Exp. Bot., 64, 899-908, 2013.

Howarth, R. W.: Nutrient limitation of net primary production in marine ecosystems, Annu. Rev. Ecol. Syst., 19, 89-110, 1988.

Hwang, R. L., Tsai, C. C., and Lee, T. M.: Assessment of temperature and nutrient limitation on seasonal dynamics among species of sargassum from a coral reef in southern taiwan, J. Phycol., 40, 463-473, 2004.

Incera, M., Olabarria, C., Troncoso, J. S., and López, J.: Response of the invader Sargassum muticum to variability in nutrient supply, Mar. Ecol.-Prog. Ser., 377, 91-101, 2009.

IPCC: Climate change 2013: The physical science basis, in: Working Group I Contribution to the Fifth Assessment Report of the
Intergovernmental Panel on Climate Change, edited by: Stocker, T. F., Qin, D., Plattner, G.-K., Tignor, M., Allen, S. K., Boschung, J., Nauels, A., Xia, Y., Bex, V., and Midgley, P. M., Cambridge Univ Press, New York, 2013.

Ji, Y., Xu, Z., Zou, D., and Gao, K.: Ecophysiological responses of marine macroalgae to climate change factors, J. Appl. Phycol., 28, 2953-2967, 2016.

Jones, G. and Farnham, W.: Japweed: new threat to British coasts, New Sci., 60, 394-395, 1973.

Kübler, J. E., Johnston, A. M., and Raven, J. A.: The effects of reduced and elevated $\mathrm{CO}_{2}$ and $\mathrm{O}_{2}$ on the seaweed Lomentaria articulata, Plant Cell Environ., 22, 1303-1310, 1999.

Karlsson, J. and Loo, L. O.: On the distribution and continuous expansion of the Japanese seaweed - Sargassum muticum - in Sweden, Bot. Mar., 42, 285-294, 1999.

Kochert, G.: Carbohydrate determination by the phenol-sulfuric acid method, in: Handbook of Phycological Methods: Physiological and Biochemical Methods, edited by: Hellebust, J. A. and Graigie, J. S., Cambridge University Press, Cambridge, 1978.

Laffoley, D. A., Roe, H. S. J., Angel, M. V., Ardron, J., Bates, N. R., Boyd, I. L., Brooke, S., Buck, K. N., Carlson, C. A., and Causey, B.: The protection and management of the Sargasso Sea: The golden floating rainforest of the Atlantic Ocean, Sargasso Sea Alliance, Washington, DC, USA, 2011.

Lapointe, B. E.: Phosphorus-limited photosynthesis and growth of Sargassum natans and Sargassum fluitans (Phaeophyceae) in the western North Atlantic, Deep-Sea Res. Pt. I, 33, 391-399, 1986.

Lapointe, B. E.: A comparison of nutrient - productivity in Sargassum natans from neritic vs. oceanic waters of the western North Atlantic Ocean, Limnol. Oceanogr., 40, 625-633, 1995.

Lapointe, B. E., Littler, M. M., and Littler, D. S.: A comparison of nutrient-limited productivity in macroalgae from a Caribbean barrier reef and from a mangrove ecosystem, Aquat. Bot., 28, 243-255, 1987.

Lapointe, B. E., Littler, M. M., and Littler, D. S.: Nutrient availability to marine macroalgae in siliciclastic versus carbonate-rich coastal waters, Estuar. Coast., 15, 75-82, 1992.

Lartigue, J. and Sherman, T. D.: Field assays for measuring nitrate reductase activity in Enteromorpha sp. (Chlorophyceae), Ulva sp. (Chlorophyceae), and Gelidium sp. (Rhodophyceae), J. Phycol., 38, 971-982, 2002.

Lartigue, J. and Sherman, T. D.: Response of Enteromorpha sp. (Chlorophyceae) to a nitrate pulse: nitrate uptake, inorganic nitrogen storage and nitrate reductase activity, Mar. Ecol.-Prog. Ser., 292, 147-157, 2005.

Lauer, M. J., Pallardy, S. G., Blevins, D. G., and Randall, D. D.: Whole leaf carbon exchange characteristics of phosphate deficient soybeans (Glycine max L.), Plant Physiol., 91, 848-854, 1989.

Lichtenthaler, H. K.: Chlorophylls and carotenoids: Pigments of photosynthetic biomembranes, Methods Enzymol., 148, 350382, 1987.

Littler, M. M., Littler, D. S., and Titlyanov, E. A.: Comparisons of $\mathrm{N}$ - and P-limited productivity between high granitic islands versus low carbonate atolls in the Seychelles Archipelago: a test of the relative-dominance paradigm, Coral Reefs, 10, 199-209, 1991.

Liu, C. and Zou, D.: Effects of elevated $\mathrm{CO}_{2}$ on the photosynthesis and nitrate reductase activity of Pyropia haitanensis (Ban- 
giales,Rhodophyta) grown at different nutrient levels, Chin. J. Oceanol. Limnol., 33, 419-429, 2015.

Liu, Y. and Tan, H.: Changes of growth and nutrient-relating enzymatic activities of Sargassum thunbergii when exposed to different nutrient conditions, Aquat. Sci. Technol., 2, 1-13, 2014.

Longphuirt, S. N., Eschmann, C., Russell, C., and Stengel, D. B.: Seasonal and species specific response of five brown macroalgae to high atmospheric $\mathrm{CO}_{2}$, Mar. Ecol.-Prog. Ser., 493, 91-102, 2014.

Mattio, L. and Payri, C. E.: 190 years of Sargassum taxonomy, facing the advent of DNA phylogenies, Bot. Rev., 77, 31-70, 2011.

Müller, S. and Mitrovic, S. M.: Phytoplankton co-limitation by nitrogen and phosphorus in a shallow reservoir: progressing from the phosphorus limitation paradigm, Hydrobiologia, 744, 255269,2015

Nakahara, K. G. H.: Effects of nutrients on the photosynthesis of Sargassum thunbergii, Bot. Mar., 33, 375-384, 1990.

Norici, A., Bazzoni, A. M., Pugnetti, A., Raven, J. A., and Giordano, M.: Impact of irradiance on the $\mathrm{C}$ allocation in the coastal marine diatom Skeletonema marinoi Sarno and Zingone, Plant Cell Environ., 34, 1666-1677, 2011.

Olivera, M., Tejera, N., Iribarne, C., Ocaña, A., and Lluch, C.: Growth, nitrogen fixation and ammonium assimilation in common bean (Phaseolus vulgaris): effect of phosphorus, Physiol. Plant., 121, 498-505, 2004.

Pierrot, D., Lewis, E., and Wallace, D. W. R.: MS Excel program developed for $\mathrm{CO}_{2}$ system calculations, ORNL/CDIAC-105a, Carbon Dioxide Information Analysis Center, Oak Ridge National Laboratory, US Department of Energy, Oak Ridge, Tennessee, 2006.

Raven, J., Caldeira, K., Elderfield, H., Hoegh-Guldberg, O., Liss, P., Riebesell, U., Shepherd, J., Turley, C., and Watson, A.: Ocean acidification due to increasing atmospheric carbon dioxide, The Royal Society, London, 2005.

Raven, J. A.: The energetics of freshwater algae; energy requirements for biosynthesis and volume regulation, New Phytol., 92, 1-20, 1982.

Roy, R. N., Roy, L. N., Vogel, K. M., Porter-Moore, C., Pearson, T., Good, C. E., Millero, F. J., and Campbell, D. M.: The dissociation constants of carbonic acid in seawater at salinities 5 to 45 and temperatures 0 to $45^{\circ} \mathrm{C}$, Mar. Chem., 44, 249-267, 1993.

Rueness, J.: Sargassum muticum and other introduced Japanese macroalgae: Biological pollution of European coasts, Mar. Pollut. Bull., 20, 173-176, 1989.

Rychter, A. M., Chauveau, M., Bomsel, J. L., and Lance, C.: The effect of phosphate deficiency on mitochondrial activity and adenylate levels in bean roots, Physiol. Plant., 84, 80-86, 2006.

Scagel, R. F.: Introduction of a Japanese alga, Sargassum muticum, into the northeast Pacific, Fisheries Research Papers, 1, 49-58, 1956.

Schaffelke, B. and Klumpp, D. W.: Nutrient-limited growth of the coral reef macroalga Sargassum baccularia and experimental growth enhancement by nutrient addition in continuous flow culture, Mar. Ecol.-Prog. Ser., 164, 199-211, 1998.

Schell, J. M., Goodwin, D. S., and Siuda, A. N. S.: Recent sargassum inundation events in the Caribbean, Oceanography, 28, 810, 2015.
Sfriso, A. and Facca, C.: Annual growth and environmental relationships of the invasive species Sargassum muticum and Undaria pinnatifida in the lagoon of Venice, Estuar. Coast. Shelf S., 129, 162-172, 2013.

Smetacek, V. and Zingone, A.: Green and golden seaweed tides on the rise, Nature, 504, 84-88, 2013.

Smith, F. A. and Raven, J. A.: Intracellular $\mathrm{pH}$ and its regulation, Annu. Rev. Plant Phys., 30, 289-311, 1979.

Smith, V. H., Tilman, G. D., and Nekola, J. C.: Eutrophication: impacts of excess nutrient inputs on freshwater, marine, and terrestrial ecosystems, Environ. Pollut., 100, 179-196, 1999.

Stæhr, P. A., Pedersen, M. F., Thomsen, M. S., Wernberg, T., and KrauseJensen, D.: Invasion of Sargassum muticum in Limfjorden (Denmark) and its possible impact on the indigenous macroalgal community, Mar. Ecol.-Prog. Ser., 207, 79-88, 2000.

Strickland, J. D. H. and Parsons, T. R.: A practical handbook of seawater analysis, 2nd Edn., Fisheries Research Board of Canada, Ottawa, 1972.

Velasco, P. J. and Whitaker, J. R.: Synthesis and degradation of nitrate reductase during the cell cycle of Chlorella sorokiniana, Plant Physiol., 89, 220-224, 1989.

Vered, I. and Shlomit, Y. R.: Phosphate and sulfur limitation responses in the chloroplast of Chlamydomonas reinhardtii, FEMS Microbiol. Lett., 283, 1-8, 2008.

Wu, H. Y., Zou, D. H., and Gao, K. S.: Impacts of increased atmospheric $\mathrm{CO}_{2}$ concentration on photosynthesis and growth of micro- and macro-algae, Sci. China Ser. C, 51, 1144-1150, 2008.

$\mathrm{Xu}$, J. and Gao, K.: Future $\mathrm{CO}_{2}$-induced ocean acidification mediates the physiological performance of a green tide alga, Plant Physiol., 160, 1762-1769, 2012.

$\mathrm{Xu}, \mathrm{Z}$., Zou, D. H., and Gao, K.: Effects of elevated $\mathrm{CO}_{2}$ and phosphorus supply on growth, photosynthesis and nutrient uptake in the marine macroalga Gracilaria lemaneiformis (Rhodophyta), Bot. Mar., 53, 123-129, 2010.

Yelle, S., Gosselin, A., and Trudel, M. J.: Effect of atmospheric $\mathrm{CO}_{2}$ concentration and root-zone temperature on growth, mineral nutrition, and nitrate reductase activity of greenhouse tomato, J. Am. Soc. Hort. Sci., 112, 1036-1040, 1987.

Zer, H. and Ohad, I.: Light, redox state, thylakoid-protein phosphorylation and signaling gene expression, Trends Biochem. Sci., 28, 467-470, 2003.

Zou, D.: Effects of elevated atmospheric $\mathrm{CO}_{2}$ on growth, photosynthesis and nitrogen metabolism in the economic brown seaweed, Hizikia fusiforme (Sargassaceae, Phaeophyta), Aquaculture, 250, 726-735, 2005.

Zou, D. and Gao, K.: Effects of desiccation and $\mathrm{CO}_{2}$ concentrations on emersed photosynthesis in Porphyra haitanensis (Bangiales, Rhodophyta), a species farmed in China, Eur. J. Phycol., 37, 587592, 2002.

Zou, D. and Gao, K.: Acquisition of inorganic carbon by Endarachne binghamiae (Scytosiphonales, Phaeophyceae), Eur. J. Phycol., 45, 117-126, 2010. 